\title{
Distribution, status and conservation of the Bengal Florican Houbaropsis bengalensis in Cambodia
}

\author{
THOMAS N. E. GRAY, NIGEL J. COLLAR, PETER J. A. DAVIDSON, \\ PAUL M. DOLMAN, TOM D. EVANS, HARRY N. FOX, HONG CHAMNAN, \\ RO BOREY, SENG KIM HOUT and ROBERT N. VAN ZALINGE
}

\section{Summary}

The Bengal Florican is a 'Critically Endangered' bustard (Otididae) restricted to India, Nepal and southern Indochina. Fewer than 500 birds are estimated to remain in the Indian subcontinent, whilst the Indochinese breeding population is primarily restricted to grasslands surrounding the Tonle Sap lake, Cambodia. We conducted the first comprehensive breeding season survey of Bengal Florican within the Tonle Sap region $\left(19,500 \mathrm{~km}^{2}\right)$. During 2005/06 and 2006/o7 we systematically sampled $\mathrm{I}-\mathrm{km}$ squares for territorial males. Bengal Florican were detected within $901-\mathrm{km}$ squares at a mean density of 0.34 males $\mathrm{km}^{-2}$ which, accounting for unequal survey effort across grassland blocks, provides a mean estimate of 0.2 males $\mathrm{km}^{-2}$. Based on 2005 habitat extent, the estimated Tonle Sap population is 416 adult males $(333-502 \pm 95 \% \mathrm{CI})$, more than half of them in Kompong Thom province. Tonle Sap grasslands are rapidly being lost due to intensification of rice cultivation and, based on satellite images, we document declines of $28 \%$ grassland cover within 10 grassland blocks between January 2005 and March 2007. Based on mean 2005 population densities the remaining grassland may support as few as 294 adult male florican, a decline of $30 \%$ since 2005. In response to these habitat declines almost $350 \mathrm{~km}^{2}$ of grassland have been designated as protected areas, set aside for biodiversity and local livelihoods. Conservation activities in these areas include participatory land-use zoning, patrols reporting new developments to government officials, awareness-raising and incentive-led nest protection schemes.

\section{Introduction}

Bengal Florican Houbaropsis bengalensis is a globally threatened bustard restricted to lowland dry or seasonally inundated alluvial grasslands and occurring in two disjunct populations; one in northern India and Nepal and the second in southern Indochina (BirdLife International 2001). The species is polygynous, with an apparent exploded lek breeding biology, and, at least within Indochina, is largely migratory, with most populations leaving breeding grasslands at the onset of the rainy season. Although the wet-season distribution is imprecisely known, birds have been recorded from grassland patches within dry dipterocarp forest, 30-60 km from known breeding grasslands. Bengal Florican has recently been uplisted to 'Critically Endangered' on the basis of rapid population decline inferred from declines in grassland extent within Cambodia (Gray 2008). The Indochinese subspecies $H . b$. blandini was first described by the French naturalist Jean Delacour from a female specimen collected from Svay Rieng province, Cambodia in June 1928 (Delacour 1929). Subsequent pre-1960 records were concentrated around the lower Mekong floodplain, in both Cambodia and adjacent Vietnam, with three reports from areas north of the 
Tonle Sap lake in Cambodia (Eames 1995, Thomas and Poole 2003, Davidson 2004). The deteriorating security situation prevented further fieldwork in Cambodia until the late 1990s and, despite the discovery in 1990 of small numbers in Dong Thap province, Vietnam, the Indochinese Bengal Florican population was believed to be tiny. Therefore global population estimates of $<400$ in the early 1980s, comprising 200-300 birds in India and $<100$ in Nepal, were still considered appropriate a decade later (Inskipp and Collar 1984, Collar et al. 1994). However in April 1999 Bengal Floricans were observed from grassland surrounding a Khmer Rouge era dam at Ang Trapeang Thmor, Banteay Meanchey province, Cambodia (Goes and Sam Veasna 1999). By 2002, subsequent fieldwork documenting the country's Important Bird Areas produced records from an additional four locations within seasonally inundated grassland surrounding the Tonle Sap lake, one location in north-west Cambodia in the margins of the Tonle Sap floodplain, and one site in the Mekong delta (Seng Kim Hout et al. 2003, Davidson 2004).

Since 2002 biological research has been undertaken at three focal grassland sites supporting breeding floricans within the Tonle Sap floodplain (sites 8: Stoung-Chikreng, 11: Veal Srangai and 12: Kruos Kraom; Figure 1; Appendix 1), resulting in a population estimate of 106-270 birds across these three sites (Davidson 2004). This estimate exceeded numbers from the largest single population in the Indian subcontinent, at Manas National Park, Assam (Choudhury 2000),

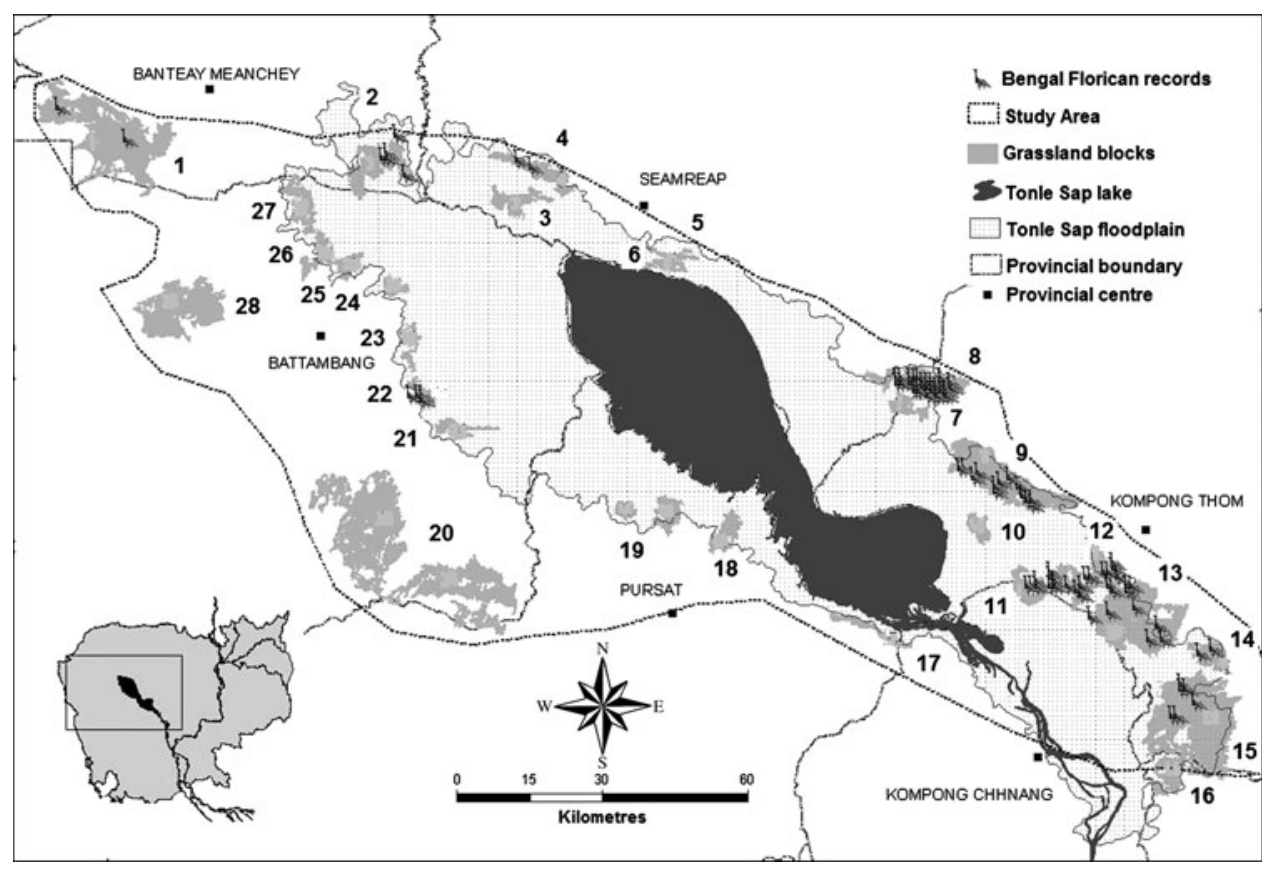

Figure 1. Grassland blocks (2005) within the Tonle Sap region and locations of Bengal Florican detected during territory surveys in 2006 and 2007. Grassland blocks identified by numbers: 1: Mongkol Borei; 2: Preah Net Preah; 3: Puok-Muok Paen; 4: Puok Lvea; 5: Kandeak; 6: Prasat Bakong; 7: Stoung Chikreng South; 8: Stoung Chikreng; 9: San Kor; 10: Chamnar Kraom; 11: Veal Srangai; 12: Kruos Kraom; 13: Kouk Preah Beung Trea; 14: Chong Doung; 15: Baray; 16: Cheung Prey; 17: Krakor; 18: Kandieng; 19: Bakan; 20: Koas Kroala; 21: Moung Russei; 22: Sangkae Kompong Pring; 23: Sangkae Preak Luong; 24: Sangkae Roka; 25: Aek Phnum; 26: Aek Phnum-Preak; 27: Thmor Kol; 28: Bavel. 
emphasising the great significance of the Cambodian population for the global conservation of the Bengal Florican. Cambodia-wide land-use classifications suggested considerable additional grassland habitat within, and at the margins of, the Tonle Sap floodplain, and further surveys and assessments of the species's status within Cambodia were considered a conservation priority (BirdLife International 2001, Davidson 2004). This paper presents the results of the first comprehensive surveys of Bengal Florican from grassland patches within and surrounding the Tonle Sap floodplain, and reviews the species's distribution and status in Cambodia. Current conservation activities being undertaken on the species are also outlined.

\section{Methods}

Study area

Tonle Sap, located in the centre of the low-lying Cambodian central plain $\left(13^{\circ} \mathrm{N}, 104^{\circ} \mathrm{E}\right)$ is the largest freshwater lake in South-East Asia. In the dry season (December-June) it covers some $2,500 \mathrm{~km}^{2}$, but in the wet season (July-November) it expands, following a reversal in the flow of the Tonle Bassac river, to between 12,500 and $15,000 \mathrm{~km}^{2}$ (Campbell et al. 2006). Our study area (henceforth Tonle Sap region) comprised just over $19,500 \mathrm{~km}^{2}$ (10.8 \% of Cambodia's land area) of which approximately $56 \%$ is within the Tonle Sap floodplain (Figure 1) The most recent Cambodia-wide land-use classification (JICA 2000), dating from 1996/97, indicates this region holds the majority of the remaining grassland in Cambodia $(>60 \%$ by area of all grassland patches $>10 \mathrm{~km}^{2}$ ). Within the Tonle Sap region, dominant vegetation types in 1996/7 were wet-season rice agriculture $(33 \%$ of area excluding permanent water in the Tonle Sap) and forest and scrublands (33\%), interspersed with grassland (21\%) and small permanent wetlands (15\%) (JICA 2000). Soils are primarily gleysols and acrisols with small areas of plinthosols, fluvisols and luvisols (MRC 2006).

\section{Survey methodology}

The Bengal Florican is a grassland specialist and, as a result of its exploded-lek breeding system, requires relatively large contiguous grassland patches (Gray 2008). Given that breeding-season home ranges of adult male Bengal Floricans $(n=8)$ are between 1.6 and $2.5 \mathrm{~km}^{2}$ (Gray et al. unpublished manuscript), leks of $>4$ males are likely to require in excess of $10 \mathrm{~km}^{2}$ of grassland. Therefore, in order to produce precautionary but statistically robust and conservative population estimates, we restricted our surveys to potentially suitable habitat, defined as within large $\left(>_{10} \mathrm{~km}^{2}\right)$ grassland blocks. These were identified, prior to field surveys, from the latest available landcover classifications for the study region, dating from January 2005 (derived from manual interpretation of colour aerial photographs) for grassland blocks within the boundaries of the Tonle Sap floodplain (Gray 2008) and from 1996 for blocks outside the floodplain (JICA 2000).

In addition to the three known focal sites, this process identified 25 grassland blocks within the Tonle Sap region: 22 (total area $1,166 \mathrm{~km}^{2}$; area $\bar{x} 53 \mathrm{~km}^{2}$ ) inside the Tonle Sap floodplain and 3 (total area $768 \mathrm{~km}^{2} ; \bar{x}$ area $256 \mathrm{~km}^{2}$ ) outside the floodplain (Figure 1). Logistics and security reasons related to unexploded ordinance and bandit activity ruled out field visits to nine of these grassland blocks (total area $205 \mathrm{~km}^{2} ; \bar{x}$ area $23 \mathrm{~km}^{2}$ ), so that surveys were restricted to the 16 remaining blocks (total area $1,729 \mathrm{~km}^{2} ; \bar{x}$ area $108 \mathrm{~km}^{2}$ ). A random subset of 1691 -km squares (from the pool of 1,729 possible 1 -km squares) within these grassland blocks was selected for survey. A $1-\mathrm{km}^{2}$ sampling unit was chosen to be relevant to the species's exploded-lek breeding biology and reflected the approximate minimum distance between adjacent territories within an exploded lek (Gray et al. 2007).

All selected 1-km squares were surveyed during the late dry season (March-June) of 2005/6 and 2006/7, the time of year when water levels are at their lowest and Bengal Floricans breed 
(Gray et al. 2007). All squares were surveyed on foot for one hour by teams consisting of two experienced observers using binoculars. During the breeding season, male floricans are highly conspicuous, with displays comprising an undulating flight sequence and an elaborate ruffling of head, neck and breast feathers whilst on the ground (Davidson 2004). Therefore during this period male Bengal Florican can be detected reliably. In order to maximize probability of detection, surveys were timed to coincide with the peak period of florican display activity, from mid-March to early June, and were conducted in the early morning (before o8h3o) or late afternoon (after 16hoo) when display activity peaks (Davidson 2004). All encounters with Bengal Florican were recorded and field teams documented presence/absence and numbers (as well as GPS coordinates) of displaying males within each square. This census technique is routinely used for Bengal Florican (Baral et al. 2003, Davidson 2004).

Since 2002, annual Bengal Florican population monitoring has been undertaken at three focal sites in Kompong Thom province, following an identical methodology to that of this study. Owing to timing and funding constraints these grassland blocks were not visited as part of the 2005/6-2006/7 surveys, so we included data from the latest surveys at these sites (99 randomly selected $1-\mathrm{km}$ squares surveyed during dry season 2004/5) in our analysis. This meant, however, that these focal sites were disproportionately represented in the final dataset relative to their area. This potential problem was overcome by analysing all survey data (i.e. $268 \mathrm{I}-\mathrm{km}$ squares from 19 grassland blocks) using a stratified sampling design in which each grassland block was treated as a single, independently surveyed, stratum (Greenwood and Robinson 2006; see Data analysis).

\section{Data analysis}

Owing to physical and ecological differences between grassland blocks, and disproportionate survey effort within three focal sites (see above), we treated each block as a discrete unit with an independent florican density. Within each surveyed grassland block we calculated the mean ( \pm standard deviation) density of territorial male florican per survey square. We then multiplied this density by the amount of grassland habitat, estimated from latest land-cover classifications (2005 for blocks within the floodplain; 1996 for those outside), to produce population estimates of territorial males within each block, with $95 \%$ confidence intervals calculated from the survey variance within that block. To estimate the total number of males across all surveyed blocks we followed the procedure outlined by Greenwood and Robinson (2006) for stratified sampling designs, treating each grassland block as a stratum within the total grassland resource. This involves calculating an overall mean estimate of density and confidence intervals, from estimates of mean florican density and standard deviations within each block, weighted by both sampling effort within the block (relative to block area) and the area contribution of that block to total grassland extent. The mean density and upper and lower confidence limits were then multiplied by total grassland extent, to estimate total numbers in 2005. For grassland blocks not visited during this survey, population estimates were produced by applying the mean estimate of density from the surveyed blocks. In the absence of actual fieldwork within these blocks, such estimates can only be regarded as indicative of potential numbers and are given without confidence intervals.

During the course of this study rapid and ongoing grassland loss, primarily driven by expansion of irrigated rice production, was noted throughout the Tonle Sap region. To explore how this habitat loss might alter our population estimates, losses of grassland per block were quantified by visual interpretation of ASTER and LANDSAT satellite images from March 2007, on which new rice developments are very obvious. These interpretations were ground-truthed with extensive field visits and an overflight. Analysis of habitat loss was restricted to the ten grassland blocks for which satellite images were available. Estimates of the potential population that these blocks could support in the longer term, once numbers reach equilibrium with available habitat, were then calculated using the estimate of remaining habitat. For grassland blocks where satellite images for 2007 were 
not available, current habitat extent, and thus potential florican population estimates, were calculated by applying average (from grassland blocks for which data were available) 2005-2007 rates of grassland loss.

\section{Results}

Bengal Florican were detected in 11 of the $19(55 \%)$ grassland blocks surveyed (Figure 1 ) with a mean density (pooling all surveyed $1-\mathrm{km}^{2}$ squares) of 0.34 males $\mathrm{km}^{-2}$ and mean density in occupied blocks of 0.39 males $\mathrm{km}^{-2}$. The overall weighted estimate of mean density across all surveyed blocks, accounting for variable survey effort between blocks, was considerably lower, at $0.2 \pm 0.05$ males $\mathrm{km}^{-2}$ (Appendix 1). Observed density within occupied blocks varied from 0.14 (Mongkol Borei) to o.8 (Sangkae Kompong Pring) males $\mathrm{km}^{-2}$ (Appendix 1), although only three grassland blocks (San Kor, Stoung Chikreng and Sangkae Kompong Pring) held densities greater than 0.5 males $\mathrm{km}^{-2}$ (Appendix 1). Grassland blocks with florican records were generally located along the north and east sectors of the Tonle region in an arc from Stoung Chikreng south-east to Baray (Figure I) with records from seven adjacent grassland blocks. Two blocks in the north of the floodplain, Puok Lvea and Preah Net Preah, held florican at low densities $\left(<0.25\right.$ males $\left.\mathrm{km}^{-2}\right)$; in contrast, the only block with florican along the western shore of the lake (Sangkae Kompong Pring) had the highest florican density recorded. One grassland block outside the floodplain, but within our Tonle Sap study region, Mongkol Borei, Banteay Meanchey, < $10 \mathrm{~km}$ from the Thai border, held Bengal Florican at low densities (o.14 males $\mathrm{km}^{-2}$ ).

The estimated territorial male florican population within all surveyed grassland blocks, based on 2005 habitat extent, was 376 (293-462 \pm 95\% CI) (Appendix 1). Three blocks, all partly or wholly within Kompong Thom province, had mean estimated populations of $>50$ territorial males, with the largest populations in San Kor (87) and Baray (65). Away from Kompong Thom, but within our Tonle Sap study region, the largest estimated populations were in Mongkol Borei (38) and Preah Net Preah (16), both in Banteay Meanchey province; the former may, however, be an overestimation as it is based on 1996 habitat availability. Based on the weighted estimate of mean density from the surveyed blocks, the total number of males expected to have been present in 2005 within the nine unvisited blocks is approximately 40 (Appendix 1), implying a total population within the Tonle Sap region in 2005 of $416(333-502 \pm 95 \% \mathrm{CI})$ territorial males (Table 1$)$. The majority of this population (62\%) occurred in Kompong Thom province $(\bar{x}$ estimated male population 258), with smaller numbers in Seam Reap (13\%), Banteay Meanchey (13\%), Battambang (4\%), Kompong Chhnang (4\%), Kompong Cham (3\%) and Pursat $(2 \%)$ provinces. Assuming equal sex ratios, and not counting non-breeding birds, the overall population within the Tonle Sap region in 2005 was therefore between 666 and 1,004, with a mean estimate of 832 individuals.

Grassland loss during 2005-2007 was quantified within 10 grassland blocks including eight which were surveyed for Bengal Florican (holding $75 \%$ of the estimated population for the Tonle Sap region). The area of grassland habitat within these blocks declined by $28 \%$ in 27 months, with four blocks losing more than two-thirds of 2005 grassland cover (Appendix 1). Losses were mostly driven by agricultural intensification, with $64 \%$ due to intensive dry-season rice developments. Additional losses were caused by unidentified agriculture (35\%), probably expansion of traditional wet-season rice, and exotic tree plantations ( $1 \%)$. Based on mean estimates of male numbers within these grassland blocks, and assuming a linear relationship between habitat loss and florican population size, these blocks may now support only 244 territorial males (compared to 336 based on 2005 habitat extent). Grassland blocks with large estimated populations were particularly affected by grassland loss with the consequence that, based on 2007 habitat, no block had a population estimate exceeding 50 males. If a similar decline in grassland has occurred in the other grassland blocks, then the total potential population of breeding males within the Tonle Sap 
region may be less than 300 (estimated male population 294), a $30 \%$ decline in comparison with 2005 estimates (Appendix 1).

\section{Discussion}

Inundated grasslands within the Tonle Sap floodplain are of exceptional importance for conservation. They support important populations of eleven globally threatened and six 'Near Threatened' bird species (BirdLife International 2001, Campbell et al. 2006), two of which, Bengal Florican and White-shouldered Ibis Pseudibis davisoni, are 'Critically Endangered'. These grasslands also represent the last extensive remnants of lowland grassland in South-East Asia (Davidson 2006). The florican's charismatic lekking display, familiarity to local people, ecotourism potential, and tolerance of a variety of grassland types and land-use processes, resulted in its identification as an appropriate flagship for promoting the conservation of Cambodia's lowland grasslands (Davidson 2004). Whilst our population estimates should be interpreted with some caution, due to the underlying assumptions discussed below, they still represent the most rigorous review of the status of Bengal Florican in Cambodia to date. In addition our survey, by being the first to cover grassland areas comprehensively throughout the Tonle Sap region, gives new information regarding the species's distribution, the relative importance of grassland areas, and the location of the largest remaining breeding leks.

\section{Validity of assumptions}

Whilst the use of ecologically distinct blocks to calculate population estimates, as opposed to simply extrapolating overall census densities across the total area of grassland, may reduce errors, our estimates rely on a number of assumptions. First we assume the amount of available grassland is the only constraint on the number of territorial birds per block, and that smaller $\left(<\right.$ 10 $\left.\mathrm{km}^{2}\right)$ grassland blocks, and other habitats adjacent to large blocks, are unsuitable. The requirement for medium-large blocks of grassland habitat is to be expected from species displaying an exploded-lek breeding biology (Wolff et al. 2002). Additional surveys, using the same methodology as in this paper, during dry seasons 2005/6 and 2006/7 of $1481-\mathrm{km}$ squares away from large grassland blocks (selected using a stratified random sampling design across a wide variety of habitat types; $25 \%$ of squares comprised grassland blocks $<10 \mathrm{~km}^{2} ; 34 \%$ rice cultivation and $41 \%$ flooded forest and scrub) detected Bengal Florican from just two squares (TNEG pers. obs.). Data from these surveys, together with the data set analysed in this paper, were used to build a predictive distribution model of florican presence within the Tonle Sap floodplain which demonstrated that florican distribution is constrained by requirements for a critical amount of grassland $\left(\bar{x} 18.4 \mathrm{~km}^{2}\right)$ within a $3-\mathrm{km}$ radius $\left(28 \mathrm{~km}^{2}\right)$ of the centre of surveyed squares (Gray 2008).

Given that our surveys were conducted over three field seasons, error in population estimates could possibly arise through failure in detection or double-counting where individuals have dispersed in response to habitat loss and are either missed altogether or counted more than once at sites surveyed in different years. However, as the three sites surveyed during 2004/5 experienced below-average habitat loss ( $\bar{x}$ grassland lost 20\% 2005-2007 versus $33 \%$ in other grassland blocks), population estimates are unlikely to be influenced by birds from these sites dispersing. Nevertheless, it is possible that following the 2004/5 survey some birds may have dispersed into these sites from other blocks experiencing high rates of habitat loss. Subsequent repeat surveys will be carried out to see whether this has been the case, although the strong site fidelity ('lek inertia') demonstrated by displaying bustards suggests that responses to habitat change are likely to be delayed (Lane et al. 2001, Osborne et al. 2007, Gray et al. unpublished radio-tracking observations).

As a result of the Bengal Florican's exploded-lek breeding system, care must also be taken when extrapolating estimates of population size over larger areas. However, as our survey squares 
were randomly selected across the area of habitat available within remaining grassland blocks, at a scale less than the exploded-lek structure, this should not have directionally biased our results (i.e. either to be over- or under-estimates), although it might have contributed to the sampling variance and broad confidence limits of predictions.

Our estimates also rely on florican detectability being high and false absences (i.e. florican recorded as absent when in fact present) rare. Within focal study sites in Kompong Thom province we have shown that surveys, using an identical methodology and the same observers to those employed in this study, detected all males holding permanent territories (Gray et al. 2007) and we are confident that detection rates during this broader study were similarly close to unity.

\section{Conservation value of Tonle Sap florican population}

Accurate assessment of the global importance of the Cambodian florican population is difficult given the lack of recent published information on population size and trends elsewhere within the species's range. Recent surveys at the three remaining grassland sites in Nepal found between 14 and 18 adult males (L. Paudel in litt. 2007), a possible decline from 16-30 in 2000-2001 (Baral et al. 2001). Estimates, with no methodology given, of the total population within Assam, India, between 1990 and 1998 were $250-380$ individuals from 10 sites, the most important, Manas National Park, holding 80-100 birds (Choudhury 2000) but large declines have subsequently been reported from this site (A. R. Rahmani in litt. 2007). A maximum of 100 individuals has been suggested as present elsewhere in India (BirdLife International 2001) including a 2001 estimate of 76-88 adult birds from four sites in Uttar Pradesh (Rahmani 2001). The status of the Bengal Florican in Vietnam is also unclear. In the late 1990s the species was recorded from four localities, with breeding confirmed at one (Eames 1995), but given large-scale habitat loss in and around these sites (Buckton et al. 1999, Tran Triet in litt. 2007) the Vietnamese population is extremely unlikely to exceed Io individuals and may already be extinct (J. Barzen in litt. 2007). The total florican population outside Cambodia in the late 1990s was therefore probably less than 550 individuals. Even if there has been no subsequent decline in these populations, our 2005 total estimates for the Tonle Sap region $(\bar{x} 832 ; 666-1,004 \pm 95 \% \mathrm{CI})$ represent between $55-65 \%$ of the total global population. Since the species's rediscovery in Cambodia in 1999 Bengal Floricans have been recorded from an additional two sites outside the Tonle Sap region: Ang Trapeang Thmor, Banteay Meanchey province in north-west Cambodia, and Boeung Prek Lapouv, Takeo province in the Mekong delta. Interviews with local conservation staff (by TNEG) suggest that populations of displaying males at these two sites are 4-5 and 2-3 respectively. Whilst wildlife surveys, covering other major regions and broad habitat types including substantial parts of protected areas and remote regions of Cambodia, have failed to detect Bengal Floricans, the possibility of additional small breeding populations cannot be discounted. Our estimates for the Tonle Sap region, although of major global significance, may therefore slightly underestimate total population size within Cambodia. However, any unlocated populations are likely to be very small and unfortunately therefore highly vulnerable to stochastic loss.

It must also be considered that estimating population from surveys of territorial males may misrepresent overall population size where sex ratios are unequal (Newson et al. 2005, Amrhein et al. 2007). Male-biased adult sex ratios are particularly prevalent in globally threatened bird species (Donald 2007). However, Great Bustard Otis tarda populations in Spain are strongly female-biased owing to unequal juvenile mortality (Martin et al. 2007) but also owing historically to trophy hunting of males (Alonso et al. 2005) which is not a factor in Bengal Florican. Donald (2007) suggested that female-biased sex ratios in birds may be associated with unusual mating systems including lekking. Furthermore, our population estimates do not account for juveniles and non-territorial males. Radio-telemetry work at Stoung Chikreng suggests males may not display until at least two years old, as two out of 10 males monitored retained a subadult (female-like) plumage and did not display during the year of capture (Gray et al. unpublished 
manuscript). Therefore we are wary of simply doubling numbers of territorial males to estimate total population size, and our estimates are best regarded as tentative.

If the rapid grassland loss we documented in 2005-2007 continues, Bengal Florican clearly merits its recent IUCN status uplisting to 'Critically Endangered', based on inferred rapid grassland loss in Cambodia. Bengal Florican and its grassland habitats must therefore now be considered a top-rank conservation priority at a global level. If the estimated generation time of the species is roughly equivalent to the 4-5 years of the similar-sized Houbara Bustard Chlamydotis undulata (Combreau et al. 2002), declines since 2005 of $>1 \%$ per month exceed the threshold for Critically Endangered of an $80 \%$ decline in potential habitat within three generations including a period before and a period after the moment of assessment (IUCN 2006). A major concern is that the largest proportional grassland losses occurred at the largest leks (e.g. San Kor and Baray). Based on 2005 population densities the remaining available habitat within the Tonle Sap region may support as few as 294 adult male floricans. However, this population estimate assumes a direct linear relationship between habitat loss and florican numbers, with no time-lag between habitat loss and population decline (unlikely for a long-lived lekking species showing strong site fidelity), and applies the average 2005-2007 Tonle Sap-wide rates of grassland loss to those grassland blocks for which 2007 habitat cover data were not available. Overall decline is therefore likely to be overestimated by this method, at least until population densities reach equilibrium with extant habitat. Together with the tendency of bustards to show lek inertia, this provides a window of opportunity for conservationists to restore and manage former grassland habitats. Such measures, through for example wildlife-friendly farming techniques improving breeding productivity within dry-season rice landscapes (Gray 2008), may reduce the extent of future population declines.

\section{Conservation prospects for Bengal Florican in Cambodia}

Tonle Sap and Mekong alluvial grasslands are one of the most poorly represented habitats within Cambodia's protected area network. Only two sites supporting Bengal Florican (Ang Trapeang Thmor and the recently declared Boeung Prek Lapouv Sarus Crane Sanctuary, each with estimated florican populations of $<10$ ) have national-level protection (Seng Kim Hout et al. 2003, S.K.H. pers. obs.). Whilst $86(4 \%)$ and $698(33 \%) \mathrm{km}^{2}$ of surveyed grassland blocks are within the Buffer and Transition Zones of the Tonle Sap Biosphere Reserve respectively, regulations and enforcement of protection are negligible, as evidenced by the rapid habitat loss recorded. Given the overall importance of the Tonle Sap grasslands for biodiversity (Campbell et al. 2006, Davidson 2006), the slowing and indeed halting of grassland loss is a top conservation priority in Cambodia.

Bengal Florican may be particularly vulnerable to decline and local extinction as a result of its lekking breeding biology (Morales et al. 2005). A high probability of extinction within 20 years exists for Great Bustard leks numbering $<30$ birds (Pinto et al. 2005) whilst abandonment of leks, and an effective halt in reproduction, has been documented in Little Bustards Tetrax tetrax when local lek size falls below six individuals (Inchausti and Bretagnolle 2005). Given that only six grassland blocks had a mean 2007 population estimate of $>20$ territorial males, and several of these are experiencing the greatest proportional loss of grassland habitat, local extinctions of Bengal Florican in Cambodia seem likely. However, modelling studies of Great Bustard in Spain have demonstrated that management interventions leading to small increases $(<25 \%)$ in annual survivorship of adult females and in breeding success can reduce probabilities of lek extinction by a factor of four (Lane and Alonso 2001). Similarly, population persistence within Little Bustard in western France is much more strongly dependent on female, than male, survivorship (Morales et al. 2005). Any measures aimed at increasing breeding success, such as incentive-led nest protection schemes (see below), should therefore be priorities in bustard conservation management. Conspecific attraction, with settlement of dispersing individuals based not only on habitat cues but also on the presence of conspecifics in existing leks, with dispersing birds 
preferentially settling at a few high-quality leks, has been demonstrated in Great Bustard (Lane et al. 2001, Alonso et al. 2004) and seems likely to occur in Bengal Florican (TNEG pers. obs.). This may lead to problems of increased vulnerability to environmental stochasticity and local resource depletion (Alonso et al. 2004, Pinto et al. 2005). Maintaining the maximum number of viable leks, and preventing further reduction in size and fragmentation of remaining grasslands, are therefore essential.

\section{Implemented conservation activities and future research priorities}

As a result of concerns over grassland habitat loss and associated florican population declines a conservation partnership, aiming to safeguard existing florican leks, was developed involving Wildlife Conservation Society Cambodia, BirdLife in Indochina and the Forestry Administration of the Cambodian government. This partnership is also supported by human rights and developmental organizations, as the Tonle Sap grasslands act as open-access common property resources and have a high livelihood value particularly for the most vulnerable households (Evans et al. 2005, Hori et al. 2006, Diepart 2007). In 2006, preliminary results of the survey described in this paper were used to identify grassland blocks to be proposed for protection under the name Integrated Farming and Biodiversity Areas (IFBAs). In August 2006 four IFBAs were established by provincial declaration in Kompong Thom province (covering $308 \mathrm{~km}^{2}$ ) and in January 2007 a fifth was declared in Seam Reap province (covering $46 \mathrm{~km}^{2}$ ). In these areas traditional human activities such as grazing, fishing and plant collection within grassland are encouraged but new dry-season rice developments, afforestation and expansion of wet-season rice plots are forbidden. Proposals have been made for an additional IFBA in Kompong Chhnang province, and for the issuance of national-level legislation that will strengthen protection for the whole network of sites. Based on our 2007 population estimates, proposed and designated IFBAs within these three provinces support approximately 100 territorial male floricans, more than $30 \%$ of the Cambodian population.

Conservation activities within IFBAs include field patrols to prevent hunting and to document any land encroachment, lobbying for support amongst government decision-makers, environmental education and awareness-raising, trialling of co-management arrangements for traditional resource use, and provision of agricultural development support on lands outside the IFBAs. There is ongoing research on livelihood issues and the biological needs of the floricans. Despite official protection of these sites, and the Bengal Florican recently being listed as nationally protected under new wildlife laws, field patrols recorded severe threats during the first year that IFBAs existed, including many new large-scale development projects of questionable legality (TDE pers. obs.). However, in a number of cases, particularly in Seam Reap province, authorities have acted on this information and ordered new development to stop. One activity that pre-dates the IFBAs by several years is an incentive-based nest-protection scheme in which villagers are financially rewarded for finding florican nests and given a second payment on the successful hatching of the clutch. Between 2005 and 2007 14 nests (10 with successfully hatched clutches) within three grassland blocks benefited from the scheme, which also reduces opportunistic hunting of female florican, egg collection and nest destruction (TNEG pers. obs.). Funds are readily available from levies paid by visiting bird-tour groups and it is intended to promote this scheme extensively around the IFBAs from 2008 onwards as a way to increase nest productivity and local community support for conservation.

All current Bengal Florican conservation measures within Cambodia are targeted at leks, as identified by surveys of displaying males during the breeding season, the methodology used in this study. However, although nests have been documented in the vicinity of male territories from four of the grassland blocks surveyed, little is known about the habitat preferences and distribution of female Bengal Florican. More than two-thirds of radio-tagged females $(n=7)$ at Stoung Chikreng appeared to leave the lek/grassland block to breed (Gray et al. unpublished manuscript) and similar behaviour, in which almost $50 \%$ of females leave the lek to nest, has 
been recorded in Great Bustards (Alonso et al. 2000). Therefore solely lek-based conservation may fail to protect areas of habitat potentially important for breeding productivity. Research into female distribution and breeding productivity with respect to habitat is urgently required.

Cambodian Bengal Floricans are also largely migratory and it will be important to identify non-breeding areas and assess threats. Although wet-season distribution is imprecisely known, males are believed to leave grassland leks in the floodplain at the onset of the Tonle Sap flood from late July and both sexes have subsequently been recorded, between August and November, from isolated grassland patches within dry dipterocarp forest $30-60 \mathrm{~km}$ outside the floodplain (Seng Kim Hout et al. 2002, RB pers. obs.). Several of the known non-breeding sites are facing serious threats from expansion of agro-industrial concessions and fast-growing timber plantations (RB pers. obs.) The migratory status of birds breeding in grassland outside the floodplain (e.g. Ang Trapeang Thmor and Mongkol Borei) is unknown. Further research into migration patterns, non-breeding season distribution, habitat associations and particularly trends in habitat loss and constraints on non-breeding season survivorship are urgently required.

\section{Acknowledgements}

This work was undertaken as part of the Integrated Farming and Biodiversity Areas Project, which is a collaborative project between the Wildlife Protection Office (WPO), the provincial authorities of Siem Reap and Kampong Thom provinces and three non-governmental organisations - Wildlife Conservation Society Cambodia Programme, BirdLife in Indochina Cambodia Programme and the Cambodian Centre for Study and Development in Agriculture (CEDAC). We thank the director of WPO, Mr Men Phymean, for his support throughout the project. The IFBA project is funded mainly by Fondation Ensemble, the Russell Train Education for Nature programme, Danida and a private donor. Bird surveys were additionally funded by BirdLife International (2006) and the British Ornithologists' Union (2007) and we thank both organizations, and in particular Jonathan Eames, Bou Vorsak and Steve Dudley. TNEG was funded by an award from the Natural Environment Research Council (NER/S/A/2004/12250). Laxman Paudel, Asad Rahmani, Jeb Barzen and Tran Triet kindly provided unpublished information on florican status in Nepal, India and Vietnam. David Emmett and an anonymous reviewer provided useful and constructive comments on a previous version of the manuscript. We also thank Sen Sienglay, Tan Thara, Mark Tarrant, Hazel Watson, Ly Sophea, Doung Sauren and Hong for invaluable contributions to fieldwork and the staff of WCS Cambodia, particularly Joe Walston, Tom Clements and Tim Solita, for logistical support and Ly Sophea for designing the figure.

\section{References}

Alonso, J. C., Morales, M. B. and Alonso, J. A. (2000) Partial migration, lek fidelity and nesting area fidelity in female great bustards Otis tarda. Condor 102: 127-136.

Alonso, J. C., Martín, C. A., Alonso, J. A., Palacín, C., Magaña, M. and Lane, S. J. (2004) Distribution dynamics of a great bustard metapopulation throughout a decade: influence of conspecific attraction and recruitment. Biodivers. Conserv. 13: 1659-1674.

Alonso, J. C., Martin, C. A., Palacin, C., Martin, B. and Magaña, M. (2005) The Great Bustard Otis tarda in Andalusia, southern Spain: status, distribution and trends. Ardeola 52: 67-78.

Amrhein, V., Kunc, H., Schmidt, R. and Naguib, M. (2007) Temporal patterns of territory settlement and detectability in mated and unmated Nightingales Luscinia megarhynchos. Ibis 149: 237-244

Baral, N., Timilsina, N. and Tamang, B. (2003) Status of Bengal florican Houbaropsis bengalensis in Nepal. Forktail 19: 51-56.

BirdLife International. (2001) Threatened birds of Asia: the BirdLife International red data book. Cambridge, UK: BirdLife International. 
Buckton, S. T., Cu, N., Tu, N. D. and Quynh, H. Q. (1999) The conservation of key wetlands in the Mekong Delta. Hanoi: BirdLife International Vietnam Programme, Conservation Report no. 12.

Campbell, I., Poole, C., Giesen, W. and Valbo-Jorgensen, J. (2006) Species diversity and ecology of Tonle Sap Great Lake, Cambodia. Aquat. Sci. 69: 355-373.

Choudhury, A. (2000) The birds of Assam. Gauhati: Gibbon Books and Worldwide Fund for Nature, India.

Collar, N. J., Crosby, M. J. and Stattersfield, A. J. (1994) Birds to watch 2: the world list of threatened birds. Cambridge, UK: BirdLife International.

Combreau, O., Qiao, J., Lawrence, M., Gao, X., Yao, J., Yang, W. and Launay, F. (2002) Breeding success in a Houbara Bustard Chlamydotis [undulata] macqueenii population on the eastern fringe of the Jungar Basin, People's Republic of China. Ibis 144 (on-line), E45-E56.

Davidson, P. (2004) The distribution, ecology and conservation status of the Bengal florican Houbaropsis bengalensis in Cambodia. MSc Thesis. School of Environmental Sciences, University of East Anglia, Norwich, U.K.

Davidson, P. (2006) The biodiversity of the Tonle Sap Biosphere Reserve: 2005 status review. Phnom Penh: UNDP/Wildlife Conservation Society.

Delacour, J. (1929) Three new subspecies from southern Indo-China. Bull. Brit. Orn. Club 49: 49-50.

Diepart, J. C. (2007) Recent land dynamics in the Tonle Sap floodplain and its impacts on the local communities. Tonle Sap Biosphere Reserve Bull. 3: 20-22.

Donald, P. F. (2007). Adult sex ratios in wild bird populations. Ibis 149: 671-692

Eames, J. C. (1995) The Bengal Florican Eupodotis bengalensis in Indochina. Forktail 11: 39-46.

Evans, T. E., Gray, T. N. E., Mouhyeang, S., Vanny, L. and Hong, C. (2005) Farming and its impact on flooded grasslands around the Tonle Sap lake. Phnom Penh: WCS Cambodia Programme.

Goes, F. and Sam Veasna (1999) The rediscovery of the Bengal Florican. Cambodia Bird News 3: 22-31.
Gray, T. N. E. (2008) The conservation and ecology of Bengal Florican Houbaropsis bengalensis in Cambodia: grasslands, people and management. PhD Thesis. School of Environmental Sciences, University of East Anglia, Norwich, U.K.

Gray, T. N. E., Hong Chamnan, Ro Borey, Collar, N. J. and Dolman, P. M. (2007) Habitat preferences of a globally threatened bustard provide support for community-based conservation in Cambodia. Biol. Conserv. 138: 341-350.

Greenwood, J. J. D. and Robinson, R. A. (2006) General census methods. Pp. $87-185$ in W. J. Sutherland, ed. Ecological census techniques: a handbook. Second edition. Cambridge, UK: Cambridge University Press.

Hori, M., Ishikawa, S., Heng, P., Thay, S., Ly, V., Nao, T. and Kurokura, H. (2006) Role of small-scale fishing in Kompong Thom Province, Cambodia. Fisheries Sci. 72: 846-854.

Inchausti, P. and Bretagnolle, V. (2005) Predicting short-term extinction risk for the declining Little Bustard (Tetrax tetrax) in intensive agricultural habitats. Biol. Conserv. 122: $375-384$.

Inskipp, C. and Collar, N. J. (1984) The Bengal florican: its conservation in Nepal. Oryx 18: 30-35.

IUCN (2006) Guidelines for using the IUCN Red List categories and criteria: Version 6.1. Prepared by the Standards and Petitions Working Group for the IUCN SSC Biodiversity Assessments Sub-Committee. Gland, Switzerland: IUCN http://app.iucn.org/ webfiles/doc/SSC/RedList/RedListGuidelines. pdf.

JICA (2000) Cambodia reconnaissance survey digital data project. Phnom Penh: Ministry of Public Works and Transportation.

Lane, S. J., and Alonso, J. C. (2001) Status and extinction probabilities of great bustard (Otis tarda) leks in Andalucía, southern Spain. Biodivers. Conserv. 10: 893-910.

Lane, S. J., Alonso, J. C. and Martín, C. A. (2001) Habitat preferences of great bustard Otis tarda flocks in the arable steppes of central Spain: are potentially suitable areas unoccupied? J. Appl. Ecol. 38: 193-203.

Martín, C. A., Alonso, J. C., Alonso, J. A., Palacín, C., Magaña, M. and Martín, B. (2007) Sex-biased juvenile survival in a bird 
with extreme size dimorphism, the great bustard Otis tarda. J. Avian Biol. 38: 335-346.

Morales, M. B., Bretagnolle, V. and Arroyo, B. (2005). Viability of the endangered little bustard Tetrax tetrax population of western France. Biodivers. Conserv. 14: 3135-3150.

MRC (2006) Soil map of the lower Mekong basin.: Mekong River Commission. Vientiane, Laos.

Newson, S. E., Woodburn, R. J. W., Noble, D. G., Baillie, S. R. and Gregory, R. D. (2005) Evaluating the Breeding Bird Survey for producing national population size and density estimates. Bird Study 52: 42-54.

Osborne, P. E., Suarez-Seoane, S. and Alonso, J. C. (2007) Behavioural mechanisms that undermine species envelope models: the cause of patchiness in the distribution of great bustards Otis tarda in Spain. Ecography 30: 819-828.

Pinto, M., Rocha, P. and Moreira, F. (2005) Long-term trends in great bustard (Otis tarda) populations in Portugal suggest concentration in single high quality area. Biol. Conserv. 124: 415-423.

Rahmani, A. (2001) Status of the Bengal florican Houbaropsis bengalensis in Uttar Pradesh, India. Unpublished report. Bombay, India: Bombay Natural History Society. Seng Kim Hout, Pech Bunnat, Poole, C., Tordoff, A. W., Davidson, P. and Delattre, E. (2003) Directory of Important Bird Areas in Cambodia: key sites for conservation. Phnom Penh: Wildlife Conservation Society.

Thomas, W. W. and Poole, C. M. (2003) An annotated list of the birds of Cambodia from 1859-1970. Forktail 19: 103-128.

Wolff, A., Dieuleveut, T., Martin, J. L. and Bretagnolle, V. (2002) Landscape context and little bustard abundance in a fragmented steppe: implications for reserve management in mosaic landscapes. Biol. Conserv. 107: 211-220.

THOMAS N. E. GRAY*, PAUL M. DOLMAN, HARRY N. FOX

School of Environmental Sciences, University of East Anglia, Norwich NR4 7TJ, U.K.

PETER J. A. DAVIDSON ${ }^{\dagger}$, TOM D. EVANS, RO BOREY ${ }^{\ddagger}$, HONG CHAMNAN $^{\S}$, ROBERT N. VAN ZALINGE

Wildlife Conservation Society Cambodia Program, P.O. Box 1620, Phnom Penh, Cambodia.

NIGEL J. COLLAR

BirdLife International, Wellbrook Court, Girton Road, Cambridge $\mathrm{CB}_{3}$ oNA, and Department of Zoology, University of Cambridge, Cambridge CB2 3 EJ, U.K.

SENG KIM HOUT ${ }^{\S}$

BirdLife Indochina Cambodia Program, \#25B Street 294, PO Box 2686, Tonle Basac, Phnom Penh, Cambodia.

${ }^{*}$ Author for correspondence; e-mail: tomnegray@hotmail.com

${ }^{\dagger}$ Current address: Bird Studies Canada British Columbia Program, 5421 Robertson Road, Delta, British Columbia, V4K 3N2, Canada.

${ }^{\ddagger}$ Also Department for Nature Conservation and Protection, Ministry of Environment, Sihanouk Boulevard, Phnom Penh, Cambodia.

${ }^{\S}$ Also Wildife Protection Office, Forestry Administration, Norodom Boulevard," Phnom Penh, Cambodia. 
Appendix 1. Recorded density and estimated (95\% CI range) population of territorial male Bengal Florican within surveyed and unsurveyed grassland blocks within the Tonle Sap region based on 2005 and 2007 habitat extent. Numbers in parentheses following grassland block name refer to Figure 1 . Area figures in parentheses $=1996 / 7$ block areas for sites outside the coverage of 2005 habitat classification. 2007 population estimates in parentheses = estimates for blocks outside the coverage of 2007 satellite images, calculated from overall rate of habitat loss. Provinces: KT Kompong Thom; KC Kompong Chhnang; BM Banteay Meanchey; SR Seam Reap; BT Battambang; PU Pursat; KM Kompong Cham.

\begin{tabular}{|c|c|c|c|c|c|c|c|c|}
\hline Block name & Province & $\begin{array}{l}2005 \text { area } \\
\left(\mathrm{km}^{2}\right)\end{array}$ & $\begin{array}{l}2007 \text { area } \\
\left(\mathrm{km}^{2}\right)\end{array}$ & $\begin{array}{l}\% \text { loss } \\
\text { 05-07 }\end{array}$ & $\begin{array}{l}2006 \text { territorial } \\
\jmath \text { density }\left(\mathrm{km}^{-2}\right)\end{array}$ & $\begin{array}{l}2005 \text { đิ pop. estimate } \\
\text { (95\% CI range) }\end{array}$ & $\begin{array}{l}2007 \hat{\jmath} \text { pop. } \\
\text { estimate }\end{array}$ & $\begin{array}{l}\text { Conservation } \\
\text { status } 2007\end{array}$ \\
\hline San Kor (8) & KT & 161 & 91 & 44 & 0.54 & $87(54-120)$ & 49 & \\
\hline Baray (15) & KT & 271 & 192 & 29 & 0.24 & $65(19-111)$ & 46 & $33 \%$ in IFBA \\
\hline Kouk Preah Beung Trea (13) & $\mathrm{KT} / \mathrm{KC}$ & 199 & 168 & 16 & 0.27 & $53(20-86)$ & 45 & $60 \%$ in IFBA \\
\hline Stoung Chikreng (9) & KT/SR & 73 & 67 & 8 & 0.68 & $49(40-59)$ & 45 & $76 \%$ in IFBA \\
\hline Mongkol Borei (I) & $\mathrm{BM}$ & $(266)$ & & & 0.14 & $38(0-88)$ & $(17)$ & \\
\hline Kruos Kraom (12) & KT & 59 & 33 & 45 & 0.30 & $17(9-26)$ & 10 & $23 \%$ in IFBA \\
\hline Preah Net Preah (2) & $\mathrm{BM}$ & 65 & & & 0.25 & $16(4-29)$ & (II) & IFBA planned \\
\hline Veal Srangai (II) & $\mathrm{KT} / \mathrm{KC}$ & 32 & 29 & 9 & 0.50 & $16(4-28)$ & 15 & $89 \%$ in IFBA \\
\hline Sangkae Kompong Pring (22) & BT & 15 & & & 0.80 & $12(6-18)$ & (9) & \\
\hline Chong Doung (14) & $\mathrm{KT}$ & 35 & 28 & 20 & 0.33 & $12(0-26)$ & 10 & $64 \%$ in IFBA \\
\hline Puok Lvea (4) & SR & 46 & 42 & 9 & 0.25 & $11(0-26)$ & 10 & \\
\hline Aek Phnum (25) & BT & 18 & & & 0.00 & o & (o) & \\
\hline Aek Phnum-Preak (26) & BT & 27 & & & 0.00 & o & (o) & \\
\hline Moung Ruessei (21) & BT & 21 & & & 0.00 & o & (o) & \\
\hline Thmor Kol (27) & BT & 40 & & & 0.00 & o & (o) & \\
\hline Bakan (19) & PU & 36 & & & 0.00 & o & (o) & \\
\hline Kandieng (18) & PU & 27 & & & 0.00 & o & (o) & \\
\hline Bavel (28) & BT & $(152)$ & & & 0.00 & o & (o) & \\
\hline Koas Kroala (20) & BT & $(350)$ & & & 0.00 & o & (o) & \\
\hline Total for surveyed blocks & & 1893 & & & & $376(293-462)$ & 267 & \\
\hline Cheung Prey (16) & KM & 55 & 36 & 35 & $(0.20)$ & 11 & 7 & \\
\hline Puok-Muok Paen (3) & SR & 35 & & & $(0.20)$ & 7 & (5) & \\
\hline Chamnar Kraom (10) & KT & 20 & & & $(0.20)$ & 4 & (3) & \\
\hline Stoung Chikreng South (7) & $\mathrm{KT} / \mathrm{SR}$ & 22 & 5 & 78 & $(0.20)$ & 4 & 1 & \\
\hline Krakor (17) & PU & 21 & & & $(0.20)$ & 4 & (3) & \\
\hline
\end{tabular}


Appendix 1. Continued.

\begin{tabular}{|c|c|c|c|c|c|c|c|c|}
\hline Block name & Province & $\begin{array}{l}2005 \text { area } \\
\left(\mathrm{km}^{2}\right)\end{array}$ & $\begin{array}{l}2007 \text { area } \\
\left(\mathrm{km}^{2}\right)\end{array}$ & $\begin{array}{l}\% \text { loss } \\
05-07\end{array}$ & $\begin{array}{l}2006 \text { territorial } \\
\text { ऽdensity }\left(\mathrm{km}^{-2}\right)\end{array}$ & $\begin{array}{l}2005 \text { đ pop. estimate } \\
(95 \% \text { CI range) }\end{array}$ & $\begin{array}{l}2007 \hat{\jmath} \text { pop. } \\
\text { estimate }\end{array}$ & $\begin{array}{l}\text { Conservation } \\
\text { status } 2007\end{array}$ \\
\hline Sangkae-Preak Luong (23) & BT & 15 & & & $(0.20)$ & 3 & (2) & \\
\hline Sangkae-Roka (24) & BT & 12 & & & $(0.20)$ & 2 & (2) & \\
\hline Prasat Bakong (6) & SR & 12 & & & $(0.20)$ & 2 & (2) & \\
\hline Kandeak (5) & SR & 13 & & & $(0.20)$ & 3 & (2) & \\
\hline $\begin{array}{l}\text { Estimate for } \\
\text { unsurveyed blocks }\end{array}$ & & & & & & 40 & 27 & \\
\hline
\end{tabular}

